rotation, and a large amount of black, because the red and green impressions have time to die out, and the blue (the most persistent) remains alone, showing like a fine fluorescent layer overlying the disc. I have not at present the time, or I would attempt to find out the excitation-periods for the different colours by this method, and I believe that a finer mode of applying it might determine the real number of colour-sensations, and allow of a decision being arrived at between the theories of Young and Hering.

J. B. HANNAY

\section{Dispersal of Freshwater Bivalves}

IN the late Mr. Darwin's interesting contribution upon this subject (NATURE, vol. xxv. p. 529), mention is made of the fact that the newts in Mr. Norgate's aquarium "frequently have one foot caught by a smail freshwater bivalve (Cyclas cornea?)." It is, perhaps, worth calling your readers' attention to a passaye which occurs in Mr. Knapp's "Journal of a Naturalist" (2nd ed. p. 316), published in 1829 , wherein, speaking of the newt, he says: "I have seen the boys in the spring of the year draw it up by their fishing lines, a very extraordinary figure, having a small shell-fish (Tellina cornea) attached to one or all of its feet the toes of the newt having been accidentally introduced into the gaping shell, in its progress on the mud at the bottom of the pool, or decidedly put in for the purpose of seizure, when the animal inhabitant closed the valves and entrapped the toes. . . .'

This record, coupled with $\mathrm{Mr}$. Norgate's statement in the article referred to, that " newts migrate at night from pond to pond, and can cross over obstacles which would be thought to be considerable," seems to point to the fact that the dispersal of bivalves by this means is more general than might at first be supposed. Frank J. Rowbotham

\section{The Horse in Motion}

IN NATURE, vol, xxv. p. 59r, you notice the publication of a work entitled "The Horse in Motion," by Dr. Stillman, and remark: "the following extract from Mr. Stanford's preface shows the exact part taken by each of those concerned in the investigations." "Will you permit me to say, if the subsequently quoted "extract" from Mr. Stanford's preface is suffered to pass uncontradicted, it will do me a great injustice and irreparable injury, At the suggestion of a gentleman, now residing in San Francisco, Mr. Stanford asked me if it was possible to photograph a favourite horse of his at full speed. I invented the means employed, submitted the result to Mr. Stanford, and accomplished the work for his private gratification, without remuneration. I subsequently suggested, invented, and patented the more elaborate system of investigation, Mr. Stanford paying the actual necessary disbursements, exclusive of the value of my time, or my personal expenses. I patented the apparatus and copyrighted the resulting photographs for my own exclusive benefit. Upon the completion of the work Mr. Stanford presented me with the apparatus. Never having asked or received any payment for the photographs, other than as mentioned, I accepted this as a voluntary gift; the apparatus under my patents being worthless for use to any one but myself. These are the facts; and on the bases of these I am preparing to assert my rights. 449, Strand, W.C., April 26 J. MUYBRIDGF

\section{DAILY WEATHER CHARTS IN THE NORTH ATLANTTC}

$W^{E}$ append to this notice one of the most important statements hitherto issued from the Meteorological Office, from which it will be seen that the Meteorological Council have resolved to undertake the preparation of Daily Weather Charts of the North Atlantic for the thirteen months commencing next August. The scheme will, without doubt, call forth a co-operation equally hearty on the part of the owners, captains, and officers of sailing vessels and steamers which cross the Atlantic.

The figures of the wreck returns for the four years ending with June. I880, show a striking diminution year by year, resulting as regards the gross totals in a steady reduction from 1805 in $1876-77$ to $89 \mathrm{r}$ in $1879-80$, or less than half the losses and casualties to shipping attributable to causes connected with the weather round the British coasts. No small part of this gratifying result may fairly be claimed as due to a gradual improvement in weather-forecasting and to a more intelligent attention now generally given to observational and instrumental indications of coming storms by those who man our fishing boats and coasting vessels. That much, however, yet remains to be done in some quarters by disseminating even the merest elementary notions of the subject was shown by the lamentable loss of life on October I4, I88r, on the morning of which day whole fleets of boats left the harbours and stood out to sea in the face of a barometer which had during the previous twelve hours gone down more than an inch.

. The object aimed at is better and fuller information than is yet possessed as to the origin, development, and progressive movement of the storms which occur over the Atlantic. This information will not only immediately benefit seamen, but also promote the science of meteorology, and thus tend directly to the improvement of the weather forecasts and storm warnings issued to the British coasts by rendering easier and more certain the interpretation of the first indications of approaching changes noted at the western stations in Ireland and Scotland. The commencement of the observations in August next has been happily chosen, it being then that observations also begin at the international Arctic stations, which have been planted by different nationalities in Kamschatka, Siberia, Nova Zembla, northern Scandinavia, Greenland, and Arctic North America. There will thus be brought to bear on the examination of the Atlantic storms a fulness of information gathered from these floating and stationary observatories which will so largely extend the field of observation chiefly on what we may call the weather-side of Europe, not hitherto attainable, which cannot but be productive of solid advantages to our seafaring population, and to all whose material interests may be benefited by a knowledge beforehand of weather changes.

The Meteorological Council, however, act wisely in warning against being over-sanguine as to the importance of the results to be obtained by the inquiry they are about to undertake. No decidedly great step is likely to be taken in the improvement of weather forecasting, as regards time and precision, until either of two things be done, namely, till either a cable be laid to Newfoundland, viâ Faro, Iceland, and Greenland, or till science has taught us to moor a ship 700 or 800 miles out in the Allantic, as a floating meteorological observatory, connected by cable with the west of Ireland.

The observations of the temperature of the surfacewater of the Atlantic it is proposed to make from the equator northwards, is one of the most important features of the investigation. By these observations, continued widely and uninterruptedly over a space of thirteen months, the great practical question of the bearing of the temperature of the surface-water of the Atlantic, particularly between lat. $30^{\circ}$ and $50^{\circ}$, on the character of coming seasons, can be investigated, and different theories on the subject be put to the proof. To take an example -it has been inquired (NATURE, vol. xxi. p. I42) whether, when the temperature of the Atlantic to the south-west of the British Islands, is decidedly above the normal temperature of the season, it does not follow, owing to the larger evaporation and other resulting effects, that Atlantic storms take a more southerly coursc than usual in thcir passage across Europe. If the storms of any particular winter pursue an easterly course to southwards, of the British Islands, that winter will, like the winter of 1870 $7 \mathrm{I}$, be a severe one; but if, on the other hand, these storms pursue a course to the northward, the winter will partake more or less of the mildness of the winter we have just passed through. Since the character of the season thus depends on the line followed by the atmospheric disturbances which occur, it results that if the track of the storms be dependent on the amount of evaporation from. 
the Atlantic, the general character of the weather of any coming season may be foretold.

The following statement has been issued from the Meteorological Office, London :--

"The Meteorological Council propose to undertake the preparation of daily weather charts of the North Atlantic Ocean for the thirteen months beginning on August I in he present year, and ending on August 31, 1883 .

"It is well known that the changes of weather which we experience are in general caused by atmospheric disturbances, which travel more or less rapidly, and undergo more or less modification during their progress. By far the larger number of the disturbances which visit the British Islands arrive on our shores from the Atlantic Ocean, and our earliest information as to any impending change is consequently derived from telegraphic reports from the Atlantic coasts, especially from the British stations at Stornoway, Mullaghmore, and Valentia, and occasionally from the Continental observatories at Rochfort and Corunna. But of the origin and previous history of these systems we have no sufficient knowledge, except in a few isolated cases.

"The Meteorological Council believe that any systematic information which can be obtained as to the origin development, and laws of motion of the atmospheric disturbances which occur over the Atlantic Ocean would promote the science of meteorology and be of immediate benefit to seamen traversing the Atlantic Ocean, and would tend directly to the improvement of the forecasts and storm warnings issued to the British coasts, ky rendering the interpretation of the first indications of approaching changes observed at the western meteorological stations more easy and certain.

"The importance of a systematic study of the weather of the North Atlantic Ocean has long been recognised, and series of daily synoptic charts, more or less resembling those now in contemplation, have been prepared at various times, not only by the Meteorological Office, but also by the Association Scientifique de France under the guidance of Leverrier, by Capt. Hoffmeyer, of the Danish Meteorological Institute, by the Deutsche Seewarte, at Hamburg, and (as a part of a wider plan) by the Chief Signal Office of the United States. But none of these charts, however valuable in other respects, supply adequate materials for a satisfactory discussion of Atlantic weather, chiefly on account of the small number of the observations upon which they are founded as compared with the magnitude of the area over which they are spread.

"Evidence of the interest attaching to the connection between English and Atlantic weather is afforded by the efforts which have been made during the last few years by the proprietors of the New York Herald to transmit to England from America telegraphic predictions of approaching disturbances, which (it is presumed) are founded on the reports of vessels arriving in America from the Atlantic Ocean. Reports such as these from a large number of vessels would be of great value; but the predictions taken by themselves cannot be utilised in a scientific investigation of weather.

"The Meteorological Council gratefully acknowledge the large measure of invaluable help which they have hitherto received from seamen and the shipping interest generally. But as the olject now proposed can only be achieved by the voluntary cooperation of an increased number of ob. servers, they feel justified in making a special appeal for assistance to the owners, captains, and officers of ships, and especially to the great companies whose steamers ply between this country and America. In a science which, like meteorology, is still in its infancy, every advance is attended with great difficulties, and the Council are well aware that it would be easy to be too sanguine as to the importance of the results to be obtained by the inquiry which they are about to undertake. But having regard to the loss of life and property occasioned by storms orr our coasts, ${ }^{1}$ they feel confident that their proposal will commend itself to the public gentrally, and will insure the active co-operation of those classes of the community for whose benefit it is primarily intended.

"It is proposed to ask for observations of the barometer, of open air and sea-surface temperatures, wind (direction and force) and weather at 8 a.m. and noon each day, with the position of the ship at noon.

"Forms for recording the observations will be supplied by the Meteorological Office, I16, Victoria Street, London, S.W., on application to the Marine Superintendent."

\section{PISCICULTURE IN THE EDINBURGH FISHERY EXHIBITION}

$\mathrm{I}$ was a happy thought of the promoters of the Fishery

Exhibition to secure the Aquarium for the use of their visitors. Although it is on a small scale, it adds largely to the amenities of the exposition, and must prove a novel sight to many inland visiturs. At most of the French fishery exhibitions, and at Arcachon in particular, an aquarium proved one of the greatest of the many attractions provided for the thousands who came to the châlet which contained the general exhibits. It must be confessed, however, that the French made more use of their aquarium than the directors of the Edinburgh Exhibition seem inclined to do-we miss some of the wonders of the deep in the shape of "fancy fishes," which we think might have been included in the present "show." There is one exhibit, however, which helps to make up for numerous deficiencies; we allude to entry No. 23 in the Catalogue, which is as follows:-

Musynski, Constantine, St, Petersburg.

Io, 000 live fry of the species Coregonus Bacri (Sigue), sent from St. Petersturg to this Exhibition (see in Aquarium).

There is much more in this simple entry than all at once meets the mind's eye. The fact of these young fish being in Edinburgh signifies a piscicultural feat of great importance. That impregnated fish eggs can be, and have been forwarded to great distances we know, but, as regards young fish, it has hitherto been a pretty general opinion that it would not be safe to send them a journey that would occupy a longer period than from twenty to thirty hours. Now we are disiliusioned as to that : in the Waverley Hall, at Edinburgh, we see ten thousand young fish in a healthy and lively state, that have come from a place which is two thousand miles distant. The problem of supplying these young fish with air during their long journey was solved in a very simple way, a glass tube of small diameter being inserted in the cork, whilst the shape of the great bottle (a carboy?) in which the fish travelled, insured the constant motion of the water. At all events, in whatever way this feat was accomplished, the young fish arrived in safety, the percentage of deaths being of no consequence-not 3 per cent., we believe. In connection with this Russian gift, a vexed question bas arisen at the Exhibition. Put in simple form, it is, Now that we have got these fish, what use can we make of them? It is quite clear that we cannot return them to Russia, and whether it would be safe to add them to the stock of any of our lochs has given rise to much controversy. It was first of all proposed to place them in Loch${ }^{2}$ The wreck return published by the Board of Trade for the year ending Jure 30,1880 (C. 2 co6) (the last published), gives on $\mathrm{p}$. 20 the following list
of casualties on cur coasts attributakle to causes connected with the

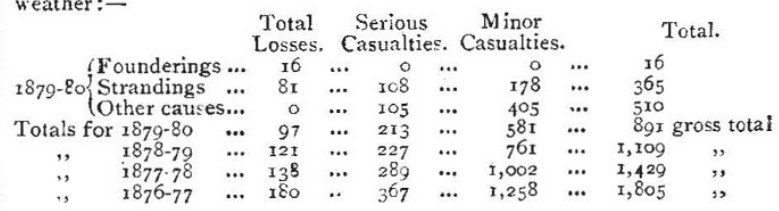

